\title{
Multidimensional Inventory of Students Quality of Life-MIS-QOL
}

\author{
Robert Szydło $^{1}$ (D), Sylwia Wiśniewska ${ }^{1}$ (D) and Małgorzata Ćwiek ${ }^{2, *(D)}$ \\ 1 Department of Labour Resources Management, Cracow University of Economics, 31-510 Cracow, Poland; \\ robert.szydlo@uek.krakow.pl (R.S.); sylwia.wisniewska@uek.krakow.pl (S.W.) \\ 2 Department of Statistics, Cracow University of Economics, 31-150 Cracow, Poland \\ * Correspondence: malgorzata.cwiek@uek.krakow.pl
}

check for

updates

Citation: Szydło, R.; Wiśniewska, S.; Ćwiek, M. Multidimensional Inventory of Students Quality of LifeMIS-QOL. Sustainability 2021, 13, 60. https://dx.doi.org/10.3390/ su13010060

Received: 20 October 2020

Accepted: 21 December 2020

Published: 23 December 2020

Publisher's Note: MDPI stays neutral with regard to jurisdictional claims in published maps and institutional affiliations.

Copyright: () 2020 by the authors. Licensee MDPI, Basel, Switzerland. This article is an open access article distributed under the terms and conditions of the Creative Commons Attribution (CC BY) license (https: / / creativecommons.org/ licenses/by/4.0/).

\begin{abstract}
An analysis of the literature on the quality of life and tools for its measurement revealed a gap in the field of research tools to study the quality of life of the so-called young adults. According to the theory of emerging adulthood, people aged 18-25 significantly differ from people of other age groups, including their self-perception. The aim of this article is to present the process of creating an inventory for multidimensional research on students' quality of life, its structural and theoretical validity as well as reliability of the tool. Structural validity of Multidimensional Inventory of Students Quality of Life (MIS-QOL) is measured by three different indicators. Comparative fit index (CFI), PCLOSE and the root mean square error (RMSEA) show good or very good structural validity of every dimension and general score. Additionally, theoretical validity of general score measured as a correlation with commonly used questionnaires show correlation on level of 0.52 with somatic subscale of WHO, 0.631 with environmental subscale of WHO, 0.657 with Satisfaction with Life Scale (SWLS), 0.703 with psychological subscale of WHO, and 0.786 with Quality of Life Scale (QOLS). Reliability of each dimension and general score measured by Cronbach alfa and split-half coefficients are above 0.7. The multidimensional construction of MIS-QOL allows researchers to compare acquired data with international research conducted by Eurostat or the OECD.
\end{abstract}

Keywords: emerging adulthood; generation Z; measuring quality of life; quality of life

\section{Introduction}

Review of literature shows the diversity the definitions of the quality of life (QOL) concept. R. Skikiewicz and K. Blonski state that origins of defining, what now is referred to as "quality of life", date back to 4th century B.C., when Hippocrates (who described happiness as the form of inner balance) and Aristotle introduced concept of Eudaimonia [1]. According to M. Abrams, quality of life is "the degree of satisfaction or dissatisfaction felt by people within various aspects of their lives" [2] (p. 35). A broad definition of quality of life is presented by D.A. Revicki, etc al. [3], who define quality of life as a comprehensive range of human experiences linked to one's overall well-being, an approach that indicates value based on subjective functioning in comparison with personal expectations and is determined by subjective perceptions, experiences, and states. Moreover, they underline that "quality of life, by its very natures, is idiosyncratic to the individual, but intuitively meaningful and understandable to most people". On the other hand, in the opinion of E. Diener, E.M. Suh, R.E. Lucas, and H.L. Smith the concept of quality of life mostly centres on how an individual measures the wellbeing of numerous aspects of their life [4]. Paunescu et al. identify three main layers that influence what is perceived by individuals and groups as "quality of life" [5]. The first layer contains personal and family beliefs and aspirations, second focuses on the social impact of communities, and third on influence of public policy. These assessments include one's disposition, emotional reactions to life occurrences, sense of life fulfilment and satisfaction, and satisfaction with personal relationships and work. 
P. Nowak stipulates to divide components of quality of life into two separate yet essential groups: first includes all objective, collectivistic, and measurable standards, and second should consist of internally perceived, nonmeasurable (subject only to self-evaluation), including psychological and cultural aspects (e.g., individual satisfaction, experiences, and ambitions) [6]. Various measurable factors should be included while assessing the quality of life-including life expectancy, public safety, education, recreation, and wellbeing. J.G. Vargas-Hernández stresses that although there is consensus regarding the essential nature of those factors, they should not be treated solely as equivalent of quality of life [7]. The author stipulates that calculated results should be described and explained from all necessary perspectives including: psychology, sociology, political sciences, environmental sciences, and economics.

Research on quality of life focuses on two basic concepts that came from two different parts of the world. The older, American, approach, started by G. Gurin, J. Veroff, and S. Field in 1957 [8] is based on the concept that the most accurate assessment of own quality of life can be made by the individual himself by measuring various dimensions of his social life [9-11]. The alternative approach comes from Scandinavia and was started by S. Johansson and co-workers in 1968 and continued by R. Erikson [12]. They focused on objective rather than subjective aspects of life.

Quality of life is a complex concept. It may be considered as an issue for individuals or groups, which combines all life aspects including culture, economy, space, and environment, etc., and describes fulfilment of many needs such as material, spiritual, safety, or ambition [6]. Moreover, it describes different sets of values, hierarchies of needs between people/groups from different backgrounds. This diversity becomes a challenge to decide on the set of key factors and their relative weights, and as a result to compare measurements done by researchers worldwide. Developing context-oriented tools that are more accurate for certain groups and applications may be an appropriate response to this challenge.

Bearing in mind the above premises, a research problem was undertaken, which was formulated in the form of questions: (1) Are commonly used tools for measuring quality of life of adults appropriate for measuring QOL of students that represent both Generation $\mathrm{Z}$ and Emerging Adulthood? (2) What are the main dimensions important for students in the context of their QOL? (3) How to measure quality of life based on the given dimensions? The purpose of the article is to present the procedure of inventory construction, its psychometric properties and issues included in particular dimensions of the questionnaire that is dedicated for measuring the QOL of students. The Abram's definition within the American approach was the base for constructing the questionnaire. The exact dimensions of students' quality of life are to be extrapolated from the pilot study.

\section{Literature Review}

\subsection{Measuring the Quality of Life}

There is a wide range of assessment tools used to measure the quality of life, but among them three are frequently used by professionals: Flanagan Quality of Life Scale (QOLS), Satisfaction with Life Scale (SWLS) and Questionnaire from World Health Organisations Quality of Life Tool (WHO-QOL).

The Flanagan QOL Scale was introduced in 1970 in the USA [13]. The original QOLS contained 15 items that represented 5 conceptual categories. Last item (16. Independence) was added later on. Conceptual categories and corresponding items are shown in Table 1 [14].

Material and Physical Wellbeing and Social, Community and Civic categories consist of two items. Three other categories consist of 4 items. It is important to state that exploratory factor analysis conducted on various groups of respondents revealed a 3-factor solution. First factor contained all 4 items $(\# 3,4,5,6)$ from the original conceptual category of Relationships with Other People as well as Social Life (\#13) and Passive Recreation (\#14) from the Recreation category. The second factor combined Material and Physical Wellbeing $(\# 1,2)$ with Professional Work (\#11) from the Personal Development category 
and Active Recreation (\#15) from the Recreation category. The last, third factor consisted of Social, Community, and Civic category items $(\# 7,8)$ and 3 of the Personal Development items $(\# 9,10,12)$. Activities related to helping others (\#7) loaded significantly more than one factor, so it could not be implemented in any of those three above [15]. The reliability measured with the Cronbach's alfa varied from 0.78 to $0.84[16,17]$ and validity measured as a Spearman's coefficient of QOLS with Life Satisfaction Index Z (LSI-Z) [18] was equal to $\mathrm{r}=0.67-0.75[15]$.

Table 1. Flanagan Quality of Life Scale.

\begin{tabular}{|c|c|}
\hline Conceptual Category & Scale Item \\
\hline Material and Physical Wellbeing & $\begin{array}{l}\text { 1. Material comforts-housing conditions, equipment and facilities, food and financial security } \\
\text { 2. Health, fitness and vigour }\end{array}$ \\
\hline Relations with Other People & $\begin{array}{l}\text { 3. Relationships with parents, siblings and extended family-communication, visiting, support } \\
\text { 4. Having and raising children } \\
\text { 5. Significant other-with a spouse or in an informal relationship } \\
\text { 6. Relations with friends }\end{array}$ \\
\hline $\begin{array}{l}\text { Social, Community, and } \\
\text { Civic Activities }\end{array}$ & $\begin{array}{l}\text { 7. Helping and supporting others, volunteering, counselling } \\
\text { 8. Involvement in organizations and public affairs }\end{array}$ \\
\hline $\begin{array}{l}\text { Personal Development and } \\
\text { Fulfilment }\end{array}$ & $\begin{array}{l}\text { 9. Learning-attending schools, gaining additional knowledge, and understanding } \\
\text { 10. Understanding of yourself, your resources and constraints, what is important in life } \\
\text { 11. Professional work and/or household chores } \\
\text { 12. Creative self-expression, creativity }\end{array}$ \\
\hline Recreation & $\begin{array}{l}\text { 13. Social life-meetings with others, joint activities, events, etc. } \\
\text { 14. Passive recreation-Reading, listening to music, watching films and TV series } \\
\text { 15. Active recreation } \\
\text { 16. Independence, "your-time" }\end{array}$ \\
\hline
\end{tabular}

Satisfaction with Life Scale (SWLS) is a second tool widely used when it comes to the quality of life measurements. It was introduced by Diener, Emmons, Larsen, and Griffin in 1985. The questionnaire consists of only 5 items:

1. In most ways my life is close to my ideal.

2. The conditions of my life are excellent.

3. I am satisfied with my life.

4. So far, I have gotten the important things I want in life.

5. If I could live my life over, I would change almost nothing.

Each of the items is being assessed by scoring from 1 to 7 where " 1 " represents strong disagreement and " 7 " represents strong agreement with the given sentence.

The validity of SWLS measured as a Pearson's correlation coefficients with the Life Satisfaction Index (LSI-A) [19], range from 0.75 to 0.81 [20,21], who have also reported a stronger correlation coefficient between the SWLS and self-reported positive affect $(\mathrm{r}=0.62)$ than between the SWLS and self-reported negative affect $(r=-0.30)$. The reliability of SWLS measured as a Cronbach alfa was equal from 0.79 to 0.89 [22,23]. For Polish adaptation it is equal to 0.81 [24].

The third tool to assesses the quality of life was created by the World Health Organization and consists of 100 items that are grouped around 6 factors: Physical Health, Psychological, Independence, Social Relations, Environment, and Spiritual (single item only) [25]. It has low psychometric value of validity measured as a Pearson's correlation between WHO-QOL and General Quality of Life Inventory $(r=0.45)$. The reliability measured with the Cronbach alfa is equal to 0.71 to 0.86 according to the subscale. The shortened version of the WHO-QOL questionnaire is called WHOQOL-BREF and consists of 26 items that allow us to calculate 4 subscale results. The validity of WHOQOL-BREF measured by Confirmatory Factor Analysis reveals the comparative fit index (CFI) on the 
level of $0.83-0.86$ for the four domain model, with root mean square error (RMSEA) equal to around 0.07 each [26].

Measuring reliability for the total sample, values for Cronbach's alfa were around 0.9. For each domain, results of internal consistency measured with Cronbach alfa were as follow: environment 0.83 , physical health scored alfa $=0.80$, psychological 0.77 , and lowest for social domain 0.69 [27]. For Polish adaptation, reliability measured with Cronbach alfa was as follows: environment 0.77 , physical health 0.81 , psychological 0.78 , and social domain 0.69: total value 0.91 [28].

The psychometric values make all three questionnaires both reliable and valid tools for measuring quality of life. Their general approach allows researchers to apply them to various groups based on criteria including age, gender, and health. They provide a huge advantage for researchers, but it is important to state that while using a general tool some important aspects can be missed, especially when the researched group stands apart from others. One such group is that of young people, members of Generation Z, whose age is classified as Emerging Adulthood.

\subsection{The Characteristics of Generation $Z$}

The term "generation" is of Greek origin and emerged from "genos", which means, "getting out of the best possible presence" [29]. In the subject literature, there is no universally accepted methodology for setting the boundaries between one generation and another. Over the years, researchers and writers have used different criteria to set the boundaries of different generations. There are considerable variations in the names and dates associated with each generation [30]. Reeves and Oh prepared a list of generational labels and dates from various sources [31] (Table 2).

Table 2. Generational Labels and Dates Reported in Different Sources.

\begin{tabular}{|c|c|c|c|c|}
\hline \multicolumn{5}{|c|}{ Generational Labels } \\
\hline \multicolumn{5}{|c|}{ Howe and Strauss (2000) } \\
\hline $\begin{array}{l}\text { Silent Generation } \\
\quad(1925-1943)\end{array}$ & $\begin{array}{c}\text { Boom Generation } \\
\quad(1943-1960)\end{array}$ & $\begin{array}{l}\text { 13th Generation } \\
\text { (1961-1981) }\end{array}$ & Millennial Generation (1982-2000) & - \\
\hline \multicolumn{5}{|c|}{ Lancaster and Stillman (2002) } \\
\hline $\begin{array}{l}\text { Traditionalists } \\
\text { (1900-1945) }\end{array}$ & $\begin{array}{c}\text { Baby Boomers } \\
(1946-1964)\end{array}$ & $\begin{array}{l}\text { Generation Xers } \\
\quad(1965-1980)\end{array}$ & $\begin{array}{c}\text { Millennial Generation; Echo Boomer; } \\
\text { Generation Y; Baby Busters; } \\
\text { Generation Next (1981-1999) }\end{array}$ & - \\
\hline \multicolumn{5}{|c|}{ Martin and Tulgan (2002) } \\
\hline $\begin{array}{l}\text { Silent Generation } \\
\quad(1925-1942)\end{array}$ & $\begin{array}{c}\text { Baby Boomers } \\
(1946-1960)\end{array}$ & $\begin{array}{c}\text { Generation X } \\
(1965-1977)\end{array}$ & Millennials (1978-2000) & - \\
\hline \multicolumn{5}{|c|}{ Oblinger and Oblinger (2005) } \\
\hline Matures $(<1946)$ & $\begin{array}{l}\text { Baby Boomers } \\
(1947-1964)\end{array}$ & $\begin{array}{c}\text { Gen-Xers } \\
(1965-1980)\end{array}$ & Gen-Y; NetGen; Millennials (1981-1995) & $\begin{array}{c}\text { Post-Millennials } \\
\text { (1995-present) }\end{array}$ \\
\hline \multicolumn{5}{|c|}{ Tapscott (1998) } \\
\hline- & $\begin{array}{l}\text { Baby Boom } \\
\text { Generation } \\
(1946-1964)\end{array}$ & $\begin{array}{c}\text { Generation X } \\
(1965-1975)\end{array}$ & Digital Generation (1976-2000) & - \\
\hline \multicolumn{5}{|c|}{ Zemke et al. (2000) } \\
\hline $\begin{array}{c}\text { Veterans } \\
(1922-1943)\end{array}$ & $\begin{array}{c}\text { Baby Boomers } \\
(1943-1960)\end{array}$ & $\begin{array}{l}\text { Gen-Xers } \\
(1960-1980)\end{array}$ & Nexters (1980-1999) & - \\
\hline
\end{tabular}

There is no consensus on the beginning of the Generation $\mathrm{Z}$ in subject literature, with researchers proposing different beginning years for this generation, for example: 1990 and after, 1995 and after, 2000 and after. Generation $\mathrm{Z}$ is also referred to by different names, such 
as: "Generation C", “Generation Cox", "Generation V", "Internet Generation", "Google Generation", "Homeland Generation", “Mobile Generation", "Selfie Generation", or "The New Silent Generation" [29].

Literature provides many characteristics that differentiate Generation $\mathrm{Z}$ from other generations. Globalization and the rapid spread of the Internet have had a great impact upon the structure of Generation Z, a generation growing with indispensable computers and technological breakthroughs. They are constantly using the Internet, social media and their applications, mp3 players, mobile phones, text messages, YouTube, or media technologies $[29,32]$.

Generation Z, also referred to as "digital natives", consists of those born in the age of the Internet. Influence of modern technology is crucial to differentiate them from previous generations. A significant factor is their ability to incorporate digital technologies into every aspect of life and difficulty with performing tasks without the use of modern tools, e.g., the Internet. Although they rapidly learn new applications and trends, generation $\mathrm{Z}$ has problems with critically assessing, selecting, and applying the information they obtain [33].

Generation $\mathrm{Z}$ is the most ethnically diverse and technologically sophisticated generation, with an informal, individual, and straightforward manner of communicating, and social networking is a vital part of their lives. They are a Do-It-Yourself generation. They are more realistic about their work expectations and optimistic about the future. Generation $\mathrm{Z}$ tends to be more entrepreneurial, trustworthy, tolerant, and less motivated by money than Generation Y. Moreover, Generation $Z$ is less narcissistic than the preceding Generation Y. Compared to previous generations, they are more optimistic about their health. They are aware that the world needs to be "better to live". They are more conscious than previous generations, because they spend their time on-line and they shape their life according to what happens there. Their friendships are mostly on social media. Because their world is a digital environment, their characteristic features are shaped like a virtual environment $[29,34]$. The expectations of Generation $\mathrm{Z}$ at the workplace centre on [34]:

- they prefer transparency, self-reliance, flexibility, and personal freedom (these preferences are non-negotiable aspects of Generation $Z$ work ethics and ignoring them could result to frustration among peers, reduced productivity, low morale, and lack of employee engagement);

- they expect to be informed and to be heard;

- they must have enough independence to prove themselves and earn immediate recognition;

- they prefer in-person or face-to-face communication and want to be treated seriously;

- they want managers to hear their ideas and value their opinions;

- they prefer work environment that cultivates mentoring, learning, and professional development opportunities as they believe that education has not given them the required skills to deal with the real life problems;

- they prefer organisations that are at the forefront of workplaces that support and allow them to communicate, edit documents, and advance work regardless of geographies or time zone barriers;

- they prefer office workplace that is easy to adjust within and they value arrangement and certainty in the workplace;

- $\quad$ they prefer to work for a leader that treats them with honesty and integrity;

- they prefer to work for an organization that demonstrates genuine ties with the community and implements social responsibility practices.

Another very specific characteristic of students is the time in their life called the emerging adulthood.

\subsection{Emerging Adulthood}

Emerging adulthood is defined as period of achievement, experimentation, and change. For many young people it is a period following the end of adolescence, and is considered to be the age of 18 to about 25 years old [35]. Many opportunities exist, 
related to both professional life (work) and personal life (love) as well as possibilities to explore the world [36]. Those factors, coupled with extending the period of education by young people and the delayed age of getting married [37] encouraged Arnett to present a new development stage concept-emerging adulthood [38]. There are three main areas that distinguish the period of emerging adulthood from teenage age and adulthood: demographics, perception of oneself, and identity shaping.

The inability to predict the situation of a person only on the basis of age reveals itself in the way of life (living alone or with parents), frequent removals, large opportunities, or lack of obligations. This is what distinguishes people at the stage of entering into adulthood from children (living with their parents and their dependence on them) and adults (permanent residence, obligations resulting from the status or commitment at work) who cannot be characterized by such high dynamics of change.

Self-perception also distinguishes the emerging adulthood from childhood and adulthood. Young people do not call themselves children, but they also do not fully define themselves as adults. They remain as if suspended between these two stages.

Arnett conducted research on a group of 519 Americans [38]. Among the questions asked was a straightforward one: "Do you think that you have reached adulthood?". People that took part in a research could choose out of three options: "yes", "no", "yes and no". The results are presented in four age groups: 12-17 years, 18-25 years, 26-35 years, and 36-55 years. People aged 12-17 mostly chose the answer "yes and no" (nearly 47\%). Thirty-eight percent of them chose the answer "no", and only about $15 \%$ answered "yes". In the group of 18-25 years, the largest number of people from all groups chose the answer "yes and no" (57\%), and 39\% chose the answer "yes". The answers "no" were negligible $(4 \%)$. In the group of people aged 26-35, the number of people choosing the answer "yes and no" was definitely lower than in the two previous ones (about 32\%). Many more of them claim that they have already reached adulthood (about 65\%). This analysis shows that age 18-25 is the age in which people are suspended between growing up and adulthood. Most of them are not sure whether they have already reached adulthood. In the next age group, this value is remarkably lower.

According to Arnett, shaping identity in the period of emerging adulthood takes place within three main areas: love, work, and views [38]. Although the beginning of these processes is placed within the adolescence period, main changes occur in the period of entering adulthood, between the ages of 18 and 25 .

In addition to three main areas characterizing the period of emerging adulthood (discussed above), there are more areas related to age-specific behaviour of young people. These include:

- Risky behaviour, which includes unprotected sex, usage of narcotics, and dangerous behaviour on the road-speeding or driving under the influence of intoxicants.

- Changing the relationship with parents, by moving from the relationship of opposition to one's parents (typical for the teenage period) towards a more partner-like relationship.

The period of emerging adulthood allows young people to discover and choose the best way to grow in adulthood. This does not exclude the importance of changes that take place in human development at later stages.

Based on the evidence provided, it seems appropriate to analyse the quality of life of students, who are in fact in the age of emerging adulthood, using a questionnaire designed especially for this group (therefore, more suitable), rather than using questionnaires made for general assessment, for kids or adults.

\section{Materials and Methods}

3.1. Questionnaire Design

Questionnaire development process was based on approach presented in various sources $[39,40]$ and expanded upon by the authors. It consisted of the following steps:

1. Defining the aim of measurement 
2. Defining the measured attribute (in accordance with Abram's definition within the American approach)

3. Recognition of dimensions significant for measured attribute

4. Pilot dimension-oriented survey

5. Identifying the dimensions significant for measured attribute and question generation process

6. Developing a unified form for questionnaire items

7. Language analysis of form and generated questions

8. Content validity analysis by competent reviewers

9. Preparation of draft questionnaire

10. Selection of questionnaires for external validity testing (Flanagan Quality of Life Scale (QOLS), Satisfaction with Life Scale (SWLS) and Questionnaire from World Health Organisations Quality of Life Tool (WHO-QOL))

11. Pilot survey including draft questionnaire as well as polish adaptations of QOLS, SWLS, and WHO-QOL

12. Exploratory factor analysis within dimensions for final questions selection

13. Questionnaire reliability assessment

14. Checking theoretical validity

15. Checking external validity based on correlation with: Flanagan Quality of Life Scale (QOLS), Satisfaction with Life Scale (SWLS) and Questionnaire from World Health Organisations Quality of Life Tool (WHO-QOL)

16. Implementation of a control scale

17. Preparing the final version of the questionnaire

18. Validation research

19. Rechecking psychometric values

The procedure of building a questionnaire was initiated by defining the goal of the questionnaire, in this case: measuring the quality of life of Generation Z students and people in emerging adulthood. The next step was the literature review, which identified 9 dimensions considered to be important for the study of students' quality of life. Validity of the indicated dimensions was subjected to a pilot study on a sample of 320 students. The research sample included $61.56 \%$ women and $38.44 \%$ men. The majority of the respondents were from Poland $(97.19 \%)$. The remaining $2.81 \%$ of the respondents were from Ukraine. Of the respondents, $21.56 \%$ lived in cities with at least 500,000 inhabitants, $19.38 \%$ in towns with 200 to 500 inhabitants. Of the surveyed students, $14.06 \%$ came from towns with 100,000 to 199,000 inhabitants and $14.69 \%$ from towns with 20,000 to 99,000 inhabitants. Moreover, $12.19 \%$ of respondents lived in small towns (less than 20,000 inhabitants) and $18.12 \%$ surveyed students lived in a village. The respondents were between 19 and 25 years old. The average age was 21.63 years with a standard deviation of 1.15. Respondents were asked "What aspects of life are You considering while thinking about your quality of life?". The respondents could also indicate their proposals for the dimensions of quality of life that were not prepared by the researchers. Based on the results of the pilot study, the importance of the previously indicated 9 dimensions of quality of life was confirmed and 3 more were added.

The next stage of work on the questionnaire consisted of creating questions that will measure the quality of life in each of the indicated dimensions. It was decided to create a vide list of questions, which was shortened based on the results of a pilot study.

The format of the item in the questionnaire was defined as a Likert-type scale with answers 1-Definitely dissatisfied, 2-Dissatisfied, 3-Rather dissatisfied, 4-Hard to say, 5-Rather satisfied, 6-Satisfied, 7-Very satisfied. Due to the fact that some items may not concern everyone, it was decided to extend the scale of answers by adding 0 -not applicable.

The generated questions were analysed in terms of linguistic correctness and content validity, which was carried out by competent reviewers. At this stage, it was also possible to reduce the number of questions from 246 to 177 and one more dimension was added. 
The initial questionnaire form was prepared in the Computerized Self-Administered Questionnaire (CSAQ) format. It is a questionnaire where the respondents could give their answers directly. The use of this technique properly excludes the problem of nonresponse, because the computer does not permit progress to the next group of questions if mandatory questions have not been answered.

The pilot study was conducted in a group of 178 randomly selected students that were asked to fill the draft questionnaire, as well as polish adaptations of QOLS, SWLS, and WHO-QOL $[28,41,42]$. On the basis of the data obtained in the pilot study, exploratory factor analysis inside the dimensions was carried out in order to establish the final list of inventory questions. The questionnaire included questions with the value of factor loads greater than (0.8). In this way, the number of questions was further reduced from 177 to 98 .

The psychometric properties of the inventory were checked in terms of reliability and validity using the following techniques and research methods:

1. The reliability of the questionnaire was estimated using Cronbach's alpha coefficients for each dimension and the split-half reliability coefficient,

2. To verify internal validity a confirmatory factor analysis (CFA) was used with CFI, RMSEA, and PCLOSE indicators,

3. The Flanagan Quality of Life Scale (QOLS), Satisfaction with Life Scale (SWLS), and Questionnaire from World Health Organisations Quality of Life Tool (WHO-QOL) were used to estimate the external validity of the questionnaire.

Before conducting the second validation study, it was decided to implement a control scale that consisted of two questions. The second validation study was conducted in a group of 182 randomly selected students. The research sample included $58.24 \%$ women and $41.76 \%$ men. The majority of the respondents were from Poland $(97.25 \%)$. The remaining $2.75 \%$ of the respondents were from Ukraine. Of the respondents, $20.88 \%$ lived in cities with at least 500,000 inhabitants, $17.03 \%$ in towns with 200 to 500 inhabitants, and $19.23 \%$ of surveyed students came from towns with 100,000 to 199,000 inhabitants and $17.03 \%$ from towns with 20,000 to 99,000 inhabitants. Moreover, $10.99 \%$ of respondents lived in small towns (less than 20,000 inhabitants) and $14.84 \%$ surveyed students lived in a village. The respondents were between 19 and 24 years old. The average age was 21.75 years with a standard deviation of 1.39 . In the validation study, the reliability and theoretical validity of the tool were re-examined.

The research was conducted in accordance with ethical standards. Participants volunteered to take part in the research. As it was made with CSAQ made with Google forms, each participant had to agree for taking part in a research by marking an appropriate answer before taking part in the research. The questionnaire was not collecting any email addresses or personal data that allows us to identify the respondent. Each of them was also informed of the possibility of withdrawing from the research at any time without consequences. The questionnaire was based on secured G-SUIT drive, accessed only by the researchers, that is in accordance with Personal Data Protection Act.

\subsection{Applied Statistical Methods}

In order to identify the questions that have the highest share in the variability of the studied dimension, exploratory factor analysis (EFA) was used. The purpose of EFA is to find a new group of variables, smaller than a group of original variables, which represent relationships between groups of many mutually correlated original variables [40].

The starting point of the analysis is the construction of entry data matrices. Each of the entry variables after its standardization is represented as a linear combination of the unobservable variables, known as the major factors, which carry the information common for the entry variables, and the unique factor, which carries the exclusive information for the entry variable, not present in any other entry variable. It is assumed that the common and unique factors are not correlated. In consequence, the variance of each entry variable 
can be represented by the variance explained by the common factors as well as by the unique factor [43]:

$$
S^{2}\left(z_{j}\right)=h_{j}^{2}+d_{j}^{2}=\sum_{l=1}^{s} w_{j l}^{2}+d_{j}^{2}=1, j=1,2, \ldots, m
$$

where: $h_{j}^{2}$-resources of common variability for $j$-variable, $d_{j}^{2}$-resources of unique variability. The factor analysis eliminates the influence of the unique factor in favour of the common factors, and by the same minimizes the influence on the values of the entry variables other than the common factors. The influence is eliminated by replacing the $\mathrm{R}$ correlation matrix of the diagonal coefficients of the correlation with the common variability resources. In the result, the below reduced correlation matrix is obtained [43]:

$$
\widetilde{R}=\left\{\begin{array}{c}
\widetilde{r}_{j j^{\prime}}=r_{j j^{\prime}}, \text { for } j \neq j^{\prime} \\
\widetilde{r}_{j j}=h_{j}^{2}, \text { for } j=j^{\prime}
\end{array}, j, j^{\prime}=1,2, \ldots, m .\right.
$$

The reduced correlation matrix serves as the basis to determine the loadings in the subsequent model equations. The loadings were estimated by means of the principal axis method. The obtained results were subject to the rotation using Varimax rotation with Kaiser normalization.

Cronbach's alpha coefficient and the Spearman-Brown split-half factor were used to validate the study. Cronbach's alpha coefficient informs what part of the variance of the total scale is the variance of the real value of this scale and is calculated from the formula [44]:

$$
\alpha=\frac{k}{k-1}\left(1-\frac{\sum_{j=1}^{k} S^{2}\left(x_{j}\right)}{S^{2}\left(x_{s}\right)}\right)
$$

A value of zero means that particular positions of the scale do not measure the true result, only generate a random error. As a result, there is no correlation between the items of the summary scale. It is assumed that the Cronbach's alpha coefficient of the tool should be at least 0.60 , while it is preferred that this coefficient be close to 0.90 .

An alternative way to calculate the reliability of a summary scale is to divide it in a certain random manner into halves. If the total scale is perfectly reliable, then the two halves are expected to be perfectly correlated (i.e., $r=1.0$ ). Less than perfect honesty will lead to a less than perfect correlation. The integrity of the summary scale can be estimated using the Spearman-Brown split-half factor, published independently by Sperman and Brown [45,46]:

$$
r_{s b}=\frac{2 r_{x y}}{1+r_{x y}}
$$

where: $r_{s b}$-split-half factor, $r_{x y}$-correlation between halves of the scale.

Confirmatory factor analysis (CFI) was applied to check the internal validity of the inventory. CFI in comparison to the exploratory factor analysis discussed earlier, is characterized by a different approach to the theory of hidden variables. EFA deals with reducing the dimensions of the studied phenomenon by detecting the optimal group of unobservable variables (factors), explaining correlations of observable variables. However, CFA is a procedure that allows us to confirm the hypothesis assuming the existence of hidden factors in the structure of the phenomenon. Confirmative factor analysis, therefore, serves to test hypotheses that can be formulated in accordance with this model [46]:

$$
x_{j}=a_{j 1} f_{1}+\ldots+a_{j k} f_{k}+d_{j} u_{j}+\delta_{j}
$$

where: $x_{j}$ - $j$-variable $(j=1, \ldots, m), f_{1}, \ldots, f_{k}$-common factors, $a_{j 1}, \ldots, a_{j k}$-loads of common factors, $u_{j}$-specific factor, $d_{j}$-load of specific factor, $\delta_{j}$-random component. The procedure of the discussed method consists of three stages. The first stage is based 
on the specification of the model. At this stage, the measurement model is constructed. In order to be able to estimate it, it must be clearly identifiable. Model identification is the subject of the second CFA stage. The final stage is the estimation of parameters and the assessment of the match. Unambiguous model traceability in practice means that each element of the variance matrix and covariance of observable variables can be presented as a function of model parameters. The necessary condition for the traceability of the model is inequality [44]:

$$
l \leq c
$$

where $l$-number of unknown, estimated model parameters, $c$ - the number of elements of the variance matrix and covariance of observable variables.

The next step is the estimation of parameters of the hypothetical model and evaluation of the goodness of their adjustment to the matrix of variance and covariance of observable variables. The first measure used to assess validity is the normalized comparative fit index (CFI). CFI measures the level of discrepancy between the obtained empirical data and the assumed model. The construction of this indicator is as follows [44]: let $l_{k}=\left[(n-1) F_{k}-d f_{k}\right]$ and $l_{0}=\left[(n-1) F_{0}-d f_{k 0}\right]$, therefore,

$$
C F I=1-\frac{l_{1}}{l_{2}}
$$

where: $l_{1}=\max \left\{l_{k}, 0\right\}, l_{2}=\max \left\{l_{k}, l_{0}, 0\right\}$. CFI takes values from the range $[0,1]$. Acceptable values are considered to be above 0.9 .

The next measure used is the root mean square error (RMSEA). It is a measure of the model fit assessmen (based on the population discrepancy function)is resistant to the number of estimated parameters. This means that it does not discriminate against models with a large number of estimated parameters. It is calculated according to the formula [43]:

$$
R M S E A=\sqrt{\frac{F_{R}}{d f_{k}}}
$$

where $F_{R}=\max \left(\frac{F_{k}-d f_{k}}{n}, 0\right)$.

The closer the RMSEA values to 0 , the better the matching of the theoretical model to the result matrix. A value not exceeding 0.05 means a good fit.

PCLOSE is a so-called proximity test assessing the probability that RMSEA is below 0.05 (the higher and more going to 1 , the better for the model, the 0.05 result is the minimum value that gives the argument that there are no grounds to reject the model) [47].

\section{Results}

Based on this process, the final Multidimensional Inventory of Student's Quality of Life was introduced, consisting of 15 dimensions and 100 questions. Dimensions and questions are presented in Table 3.

Table 3. Dimensions and questions of Multidimensional Inventory of Student's Quality of Life (MIS-QOL).

1. Finance-To what extent are You satisfied with:

- your financial security;

- $\quad$ the possibility of satisfying your own needs;

- amount of money received from scholarships;

- the possibilities of unrestricted financial self-management;

- opportunities to obtain scholarships;

- the possibility of spending financial resources for pleasure? 
Table 3. Cont.

2. Health-To what extent are You satisfied with:

- your physical condition;

- quality of advice from your medical doctor/(General Practitioner);

- $\quad$ quality of medical advice from your specialist doctors;

- availability of information about your health;

- quality of public health care;

- the access to a specialist doctor?

3. Family-To what extent are You satisfied with:

- $\quad$ time spent together with your closest family;

- $\quad$ frequency of contacts with the closest family (phone, Skype, meetings ... );

- the level of acceptance of the current partner/his absence;

- $\quad$ ways of making joint decisions;

- the level of trust in the closest family;

- $\quad$ support from the family in difficult life situations?

4. Partners-To what extent are You satisfied with:

- the level of trust in relations with him/her;

- $\quad$ time spent together;

- $\quad$ partner's respect for my principles;

- the impact he/she has on me;

- $\quad$ partner's respect for my limits;

- frequency of meetings?

5. Friends-To what extent are You satisfied with:

- network of contacts built thanks to them;

- their respect of my limits;

- time spent together with them;

- number of friends;

- $\quad$ respect for my principles;

- frequency of contacts with them?

6. Work-To what extent are You satisfied with:

- opportunities for future promotion;

- relations with superiors;

- correlation of the work performed to your education;

- relationships with colleagues;

- $\quad$ atmosphere at work;

- prestige of work?

7. Free time-To what extent are You satisfied with:

- amount of free time;

- $\quad$ quality of free time;

- $\quad$ access to sports events;

- $\quad$ travel possibilities;

- $\quad$ the freedom to decide on the form of spending free time;

- $\quad$ access to cultural events?

8. Flat/apartment-To what extent are You satisfied with:

- equipment;

- the size of the flat;

- technical condition;

- the size of the room;

- location;

- $\quad$ relations with flatmates?

9. Hobby/Interests/Passion-To what extent are You satisfied with:

- belonging to the group of "hobbyists";

- $\quad$ spreading interest in your hobby among your friends;

- the amount of time spent on the hobby;

- $\quad$ social perception of people sharing your hobby;

- the availability of places to develop a hobby;

- the level of your hobby development? 
Table 3. Cont.

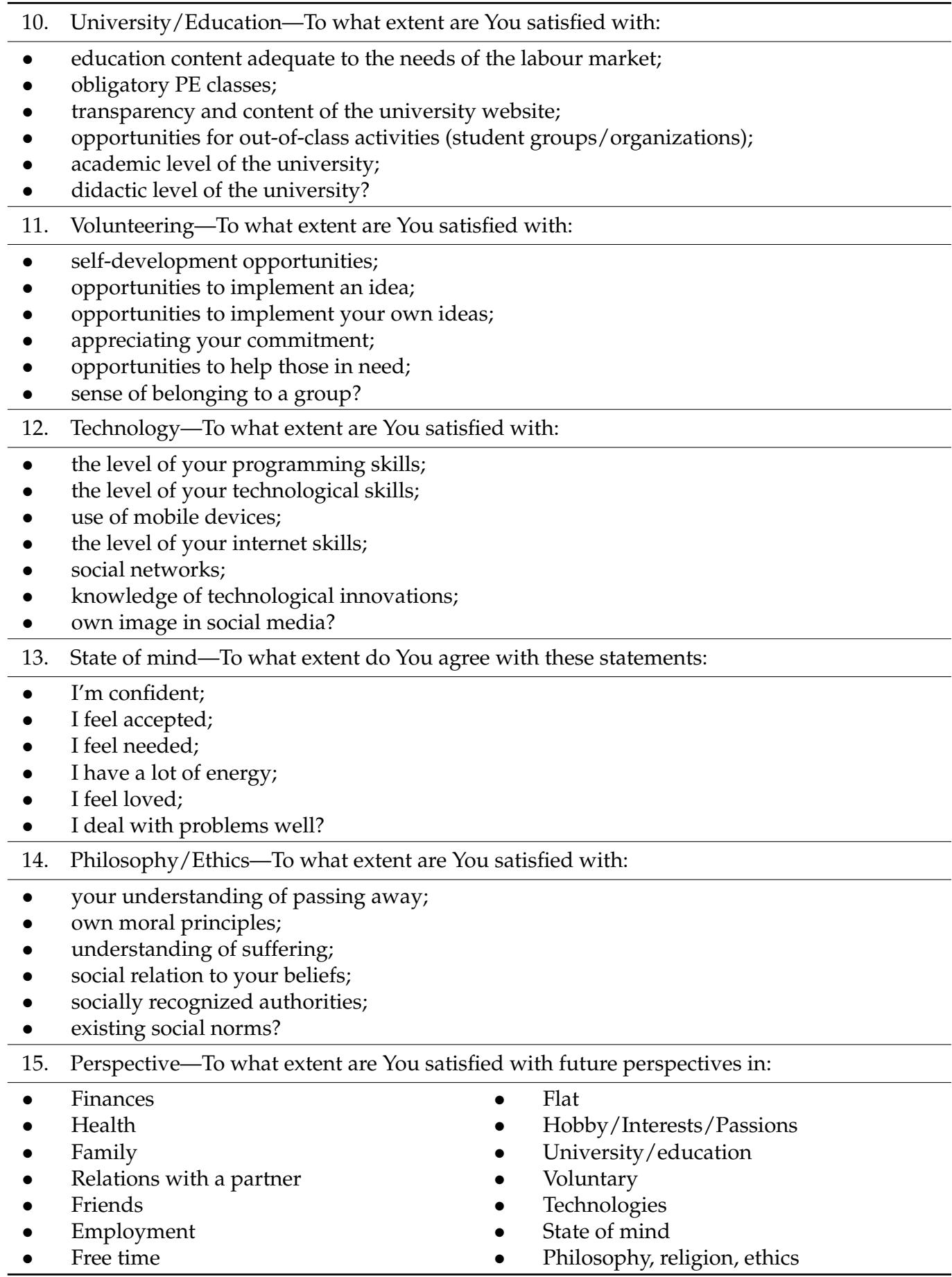

All questions in each dimension are described based on a 7-degree Likert scale. Apart from 15 dimensions, there are also two questions that serve as a control scale:

1. While assessing my own life I can say that?

2. How do You assess Your own life?

Most important indicators for inventories like that are connected with validity and reliability of each dimension of MIS-QOL. Results of analysis are presented in Table 4. 
Table 4. Results of psychometric analysis.

\begin{tabular}{cccccc}
\hline \multirow{2}{*}{ Specification } & \multicolumn{3}{c}{ Structural Validity } & \multicolumn{2}{c}{ Reliability } \\
\cline { 2 - 6 } & CFI & PCLOSE & RMSEA & Cronbach Alfa & Split-Half Coefficient \\
\hline Finance & 0.986 & 0.139 & 0.082 & 0.871 & 0.943 \\
Health & 0.978 & 0.303 & 0.064 & 0.748 & 0.783 \\
Family & 0.997 & 0.514 & 0.04 & 0.819 & 0.914 \\
Partners & 0.983 & 0.272 & 0.066 & 0.788 & 0.851 \\
Friends & 0.988 & 0.155 & 0.081 & 0.873 & 0.912 \\
Work & 1 & 0.765 & 0 & 0.804 & 0.88 \\
Free time & 0.965 & 0.072 & 0.093 & 0.813 & 0.858 \\
Flat & 0.992 & 0.269 & 0.068 & 0.74 & 0.865 \\
Hobby/Interests/Passions & 0.985 & 0.199 & 0.076 & 0.865 & 0.894 \\
University/Education & 0.99 & 0.38 & 0.056 & 0.706 & 0.756 \\
Volunteering & 1 & 0.653 & 0.013 & 0.911 & 0.943 \\
Technology & 0.995 & 0.559 & 0.033 & 0.792 & 0.792 \\
State of mind & 0.995 & 0.446 & 0.049 & 0.883 & 0.878 \\
Philosophy/Ethics & 0.984 & 0.231 & 0.071 & 0.785 & 0.803 \\
Perspective & & & & 0.892 & 0.854 \\
\hline
\end{tabular}

MIS-QOL allows us not only to calculate scores for each dimension, but also the general result. The general result is calculated by adding all the scores from each question, except the control scale. The psychometric results of the general scale are presented in Tables 5 and 6 .

Table 5. Results of psychometric analysis of MIS-QOL general score.

\begin{tabular}{cccccc}
\hline \multirow{2}{*}{ Specification } & \multicolumn{3}{c}{ Structural Validity } & \multicolumn{2}{c}{ Reliability } \\
\cline { 2 - 6 } & CFI & PCLOSE & RMSEA & Cronbach Alfa & Split-Half Coefficient \\
\hline General Score & 0.841 & 0.035 & 0.07 & 0.802 & 0.858 \\
\hline
\end{tabular}

Table 6. Theoretical validity of MIS-QOL by Pearson's Coefficient.

\begin{tabular}{cccccc}
\hline Specification & SWLS & QOLS (Flanegan) & WHO-Somatic & WHO-Psychological & WHO-Environmental \\
\hline General Score & 0.657 & 0.786 & 0.52 & 0.703 & 0.631 \\
\hline
\end{tabular}

The psychometric values of validity and reliability of second validation sample are presented in Table 7.

Table 7. Psychometric values of 2 nd validation sample.

\begin{tabular}{|c|c|c|c|c|c|c|}
\hline \multirow{2}{*}{ Specification } & \multirow[b]{2}{*}{ Research } & \multicolumn{3}{|c|}{ Structural Validity } & \multicolumn{2}{|c|}{ Reliability } \\
\hline & & CFI & PCLOSE & RMSEA & Cronbach Alfa & Split-Half Coefficient \\
\hline \multirow{2}{*}{ Finance } & Original & 0.986 & 0.139 & 0.082 & 0.871 & 0.943 \\
\hline & Validation & 0.984 & 0.065 & 0.094 & 0.901 & 0.954 \\
\hline \multirow{2}{*}{ Health } & Original & 0.978 & 0.303 & 0.064 & 0.748 & 0.783 \\
\hline & Validation & 0.955 & 0.077 & 0.094 & 0.847 & 0.84 \\
\hline \multirow{2}{*}{ Family } & Original & 0.997 & 0.514 & 0.04 & 0.819 & 0.914 \\
\hline & Validation & 0.994 & 0.343 & 0.04 & 0.919 & 0.939 \\
\hline \multirow{2}{*}{ Partners } & Original & 0.983 & 0.272 & 0.066 & 0.788 & 0.851 \\
\hline & Validation & 0.982 & 0 & 0.145 & 0.919 & 0.939 \\
\hline \multirow{2}{*}{ Friends } & Original & 0.988 & 0.155 & 0.081 & 0.873 & 0.912 \\
\hline & Validation & 0.994 & 0.434 & 0.05 & 0.889 & 0.894 \\
\hline
\end{tabular}


Table 7. Cont.

\begin{tabular}{|c|c|c|c|c|c|c|}
\hline \multirow{2}{*}{ Specification } & \multirow[b]{2}{*}{ Research } & \multicolumn{3}{|c|}{ Structural Validity } & \multicolumn{2}{|c|}{ Reliability } \\
\hline & & CFI & PCLOSE & RMSEA & Cronbach Alfa & Split-Half Coefficient \\
\hline \multirow{2}{*}{ Work } & Original & 1 & 0.765 & 0 & 0.804 & 0.88 \\
\hline & Validation & 0.956 & 0.022 & 0.108 & 0.864 & 0.874 \\
\hline \multirow{2}{*}{ Free time } & Original & 0.965 & 0.072 & 0.093 & 0.813 & 0.858 \\
\hline & Validation & 0.97 & 0.08 & 0.091 & 0.839 & 0.861 \\
\hline \multirow{2}{*}{ Flat } & Original & 0.992 & 0.269 & 0.068 & 0.74 & 0.865 \\
\hline & Validation & 0.994 & 0.325 & 0.062 & 0.862 & 0.849 \\
\hline \multirow{2}{*}{ Hobby/Interests/Passion } & Original & 0.985 & 0.199 & 0.076 & 0.865 & 0.894 \\
\hline & Validation & 0.997 & 0.517 & 0.041 & 0.922 & 0.925 \\
\hline \multirow{2}{*}{ University/Education } & Original & 0.99 & 0.38 & 0.056 & 0.706 & 0.756 \\
\hline & Validation & 0.984 & 0.104 & 0.091 & 0.798 & 0.791 \\
\hline \multirow{2}{*}{ Volunteering } & Original & 1 & 0.653 & 0.013 & 0.911 & 0.943 \\
\hline & Validation & 0.997 & 0.26 & 0.069 & 0.982 & 0.983 \\
\hline \multirow{2}{*}{ Technology } & Original & 0.995 & 0.559 & 0.033 & 0.792 & 0.792 \\
\hline & Validation & 0.992 & 0.384 & 0.055 & 0.745 & 0.815 \\
\hline \multirow{2}{*}{ State of mind } & Original & 0.995 & 0.446 & 0.049 & 0.883 & 0.878 \\
\hline & Validation & 0.996 & 0.515 & 0.049 & 0.896 & 0.909 \\
\hline \multirow{2}{*}{ Philosophy/Etics } & Original & 0.984 & 0.231 & 0.071 & 0.785 & 0.803 \\
\hline & Validation & 0.964 & 0.007 & 0.12 & 0.877 & 0.904 \\
\hline \multirow{2}{*}{ Perspective } & Original & - & - & - & 0.892 & 0.854 \\
\hline & Validation & - & - & - & 0.877 & 0.904 \\
\hline
\end{tabular}

\section{Discussion}

The proposed procedure's first pilot study was conducted to determine the most important dimensions of quality of life for young people in emerging adulthood. The top rated dimensions are finance, health, family, work, friends, and free time. When considering commonly used general questionnaires for quality of life measurement it is important to note that they are not fully adequate to the needs of young people in emerging adulthood. The dimensions included in each, are presented in Table 8.

Table 8. Dimensions covered in various quality of life questionnaires and methodologies.

\begin{tabular}{|c|c|c|}
\hline SWLS & QOLS (Flanegan) & WHO-QOL \\
\hline In most ways my life is close to my ideal & Material and Physical Wellbeing & Physical \\
\hline The conditions of my life are excellent. & Relationship & Psychological \\
\hline I am satisfied with my life. & Social, Community and Civic & Social relationships \\
\hline $\begin{array}{l}\text { So far I have gotten the important } \\
\text { things I want in life. }\end{array}$ & Personal Development & Environment \\
\hline $\begin{array}{l}\text { If I could relive my life, I would change } \\
\text { almost nothing. }\end{array}$ & Recreation & \\
\hline
\end{tabular}

SWLS assesses only the general attitude towards quality of life and does not focus on any of the dimensions important to young people [48-50]. QOLS includes almost all important aspects on a moderate level, but does not cover work [51-53]. While most of 
the dimensions are covered it is mainly based on single question assessment. It is hard to trust results based on a single question-it is possible to assess the general score, but not the one connected with a given dimension. The WHO-QOL questionnaire consists of four dimensions [54-56]. In those dimensions, free time is assessed in one question, and finance, family, and friend dimensions are assessed in two questions. Simultaneously, work is assessed in 4 questions and health dimension and health related aspects are overrepresented. MIS-QOL allows us to acquire a deeper understanding of important dimensions.

Apart from general questionnaires, there are also some related to specific aspects. Mostly, they are used for medical purposes and focus on health related issues, forgetting that some other aspects might be important for patients and that some other topics might be used for rehabilitation purposes.

The multidimensional construction of MIS-QOL allows researchers to compare acquired data not only with normalization created for different groups, but also to compare them with international research conducted by Eurostat or the OECD [57-64]. The approach represented by both institutions is based on assessing a dimension through a single, direct question. With detailed information from MIS-QOL much more advanced analysis is possible. Table 9 presents dimensions that may be easily compared.

This comparison shows that detailed information from MIS-QOL may be easily compared against large databases, which allows researchers to compare acquired data with large data sets from different countries.

The structural validity of MIS-QOL is measured by three different indicators. CFI, PCLOSE, and RMSEA show good or very good structural validity of every dimension and general score. Additionally, theoretical validity of general score measured as a correlation with commonly used questionnaires show correlation on level of 0.52 with somatic subscale of WHO, 0.631 with environmental subscale of WHO, 0.657 with SWLS, 0.703 with psychological subscale of WHO, and 0.786 with QOLS. Reliability of each dimension and general score measured by Cronbach alfa are above 0.7 , with 9 dimensions scoring above 0.8 and one above 0.9 . The results of split-half coefficients are even better: all dimensions and general score above 0.7 , out of which 9 score above 0.8 and 4 above 0.9 .

Table 9. Dimensions of quality of life.

\begin{tabular}{ccc}
\hline MIS-QOL & Eurostat & OECD \\
\hline Flat & Housing & Housing \\
Work & Employment & Jobs \\
University/Education & Education & Education \\
Hobby, volunteering & Governance & Civic Engagement \\
State of mind, philosophy & Satisfaction & Life Satisfaction \\
Free time & Time use & Work-Life balance \\
Finance & Material conditions & Income \\
Family, Partners, Friends & Social relations & Community \\
Technology, Perspective & Environment & Environment \\
Health & Health & Health \\
- & Safety & Safety
\end{tabular}

Data from original questionnaire created and validated at the Cracow University of Economics were repeated during second validation research. Most of the dimensions received similar or even better scores in validity and reliability. Scores of three of them were not acceptable. The scores of relations, work, and philosophy dimensions received acceptable score of CFI indicator but no acceptable scores in RMSEA and PCLOSE, which means that one out of three indicators is very good, and the rest show some errors in the validity of those dimensions. It states that those three dimensions require further research. 


\section{Conclusions and Limitations}

All characteristics mentioned above allow for the conclusion that the created multidimensional inventory called MIS-QOL is a valid and reliable tool for measurement quality of life of young people in emerging adulthood and quality of life of Generation Z.

The Multidimensional Inventory of Student's-Quality Of Life is not created as a perfect tool. It has a few limitations:

1. The first one is that MIS-QOL is not created based on a given theory-it is based on people's perceptions, which makes it harder to explain the theoretical aspects. There is also no guarantee that the dimensions used in the Inventory cover all important aspects-there still may be other important issues to cover.

2. It was created at Cracow University of Economics, which is a university focused on Economy, Management, and Finance. Although the second validation process was conducted with students from other universities, it is still necessary to continue validation processes.

3. Two main criteria of MIS-QOL are that it is connected with emerging adulthood and serves as a multidimensional tool. Authors could not find detailed records of quality of life of young people in emerging adulthood, which makes it harder to fully describe the validity of a tool.

4. The multidimensional perspective enables us to cover a wide range of topics, and even with internal structure of each dimension, it is mandatory to deepen the analysis in a given dimension to reveal its full description.

All the limitations of the MIS-QOL do not discredit the tool, but show the need for further research, also conducted in various countries.

Based on current state of the MIS-QOL there are several actions planned, aimed at refining the tools:

1. Gathering data from various universities and preparation of normalization of the results among various criteria, such as gender, university type, form of study;

2. Preparing the online version of the questionnaire;

3. Preparation of a shortened version of the tool for research purposes;

4. Starting cooperation with international researchers and preparing national versions of MIS-QOL based on a retranslation procedure and direct contact between authors and researchers.

After the abovementioned steps, various comparative analysis will be prepared. Authors are encouraging all interested researchers to contact us and to work together on national versions of the MIS-QOL. It is also important to state that the complexity of the Inventory enables usage in various fields of science, such as economy, management, medicine, education, psychology, and sociology.

Author Contributions: Conceptualization, R.S.; methodology, R.S. and M.Ć.; software, R.S. and M.Ć.; formal analysis, S.W.; investigation, M.Ć.; resources, S.W.; data curation, M.Ć.; writing-original draft preparation, S.W.; writing—review and editing, R.S., S.W. and M.Ć.; funding acquisition, R.S., S.W. and M.Ć. All authors have read and agreed to the published version of the manuscript.

Funding: The Project has been financed by the Ministry of Science and Higher Education within "Regional Initiative of Excellence" Programme for 2019-2022. Project no.: 021/RID/2018/19. Total financing: 11897131.40 PLN.

Acknowledgments: Authors would like to give thanks to Marek Koczyński, research assistant from the Departament of Labour Resource Management at Cracow University of Economics for his efforts during MIS-QOL preparation.

Conflicts of Interest: The authors declare no conflict of interest.

\section{References}

1. Skikiewicz, R.; Blonski, K. Economic sentiment level versus the quality of life in European Union member states. Prague Econ. Pap. 2018, 27, 379-396. [CrossRef] 
2. Abrams, M. Subjective social indicators. Soc. Trends 1973, 4, 35-50.

3. Revicki, D.A.; Osoba, D.; Fairclough, D.; Barofsky, I.; Berzon, R.; Leidy, N.K.; Rothman, M. Recommendations on health-related quality of life research to support labeling and promotional claims in the United States. Qual. Life Res. 2000, 9, 887-900. [CrossRef]

4. Diener, E.; Suh, E.M.; Lucas, R.E.; Smith, H.L. Subjective well-being: Three decades of progress. Psychol. Bull. 1999, 125, 276-302. [CrossRef]

5. Paunescu, M.; Grigore, V.; Mitrache, G.; Predoiu, A.; Predoiu, R. Quantitative and qualitative in measuring quality of life in sports. Rev. Rom. Pentru Educ. Multidimens 2018, 10, 95-108. [CrossRef]

6. Nowak, P. Regional Variety in quality of life in Poland. Oeconomia Copernic. 2018, 9, 381-401. [CrossRef]

7. Vargas-Hernández, J.G. Women entrepreneurship to improve the quality of life through best practices in rural microbusiness: A resources and capabilities approach. Econ. Mark. Commun. Rev. 2016, 6, 48-65. [CrossRef]

8. Gurin, G.; Field, S.; Veroff, J. Americans View Their Mental Health; Basic Books: New York, NY, USA, 1960.

9. Bradburn, N.M. The Structure of Psychological Well-Being; Aldine Publishing Company: Chicago, IL, USA, 1969.

10. Cantril, H. The Pattern of Human Concerns; Rutgers University Press: New York, NY, USA, 1966.

11. Andrews, M.F.; Withey, S.B. Social Indicators of Well-Being. Americans Perceptions of Life Quality; Plenum Press: New York, NY, USA; London, UK, 1976.

12. Erikson, R. Descriptions of inequality: The Swedish approach to welfare research. In The Quality of Life; Nussbaum, M., Sen, A., Eds.; Clarendon Press: Oxford, UK, 1993.

13. Flanagan, J.C. Measurement of quality of life: Current state of the art. Arch. Phys. Med. Rehabil. 1982, 63, 56-59. [PubMed]

14. Flanagan, J.C. A research approach to improving our quality of life. Am. Psychol. 1978, 33, 138-147. [CrossRef]

15. Burckhardt, C.S.; Anderson, K.L.; Archenholtz, B.; Hagg, O. The Flanagan quality of life scale: Evidence of construct validity. Health Qual. Life Outcomes 2003, 23, 1-59.

16. Anderson, K.L. The effect of chronic obstructive pulmonary disease on quality of life. Res. Nurs. Health 1995, 18, 547-556. [CrossRef]

17. Neuman, L.; Buskila, D. Measuring the quality of life of women with fibromyalgia: A Hebrew version of the quality of life scale (QOLS). J. Musculoskelet. Pain 1997, 5, 5-17. [CrossRef]

18. Wood, V.; Wylie, M.L.; Sheafor, B. An analysis of a short self-report measure of life satisfaction: Correlation with rater judgements. J. Gerontol. 1969, 24, 465-469. [CrossRef] [PubMed]

19. Neugarten, B.L.; Havinghurst, R.J.; Tobin, S.S. The measurement of life satisfaction. J. Gerontol. 1961, 31, 134-143. [CrossRef] [PubMed]

20. Abdallah, T. The Satisfaction with Life Scale (SWLS): Psychometric properties in an Arabic-speaking sample. Int. J. Adolesc. Youth 1998, 7, 113-119. [CrossRef]

21. Pavot, W.; Diener, E.E.; Colvin, C.R.; Sandvik, E. Further validation of the satisfaction with life scale: Evidence for cross-method convergence of well-being measures. J. Pers. Assess. 1991, 57, 149-161. [CrossRef]

22. Blais, M.R.; Vallerand, R.J.; Pelletier, L.G.; Briere, N.M. L'Echelle de satisfaction de vie: Validation Canadienne-Francaise du "Satisfaction with Life Scale". Can. J. Behav. Sci. Rev. 1989, 21, 210-223. [CrossRef]

23. Alfonso, V.C.; Allison, D.B.; Rader, D.E.; Gorman, B.S. The extended satisfaction with life scale: Development and psychometric properties. Soc. Indic. Res. 1996, 38, 275-301. [CrossRef]

24. Juczyński, Z. Narzędzia POMIARU w PROMOCJI Psychologii Zdrowia; Pracownia Testów Psychologicznych Polskiego Towarzystwa Psychologicznego: Warsaw, Poland, 2009.

25. WHO, Division of Mental Health and Prevention of Substance Abuse. WHOQOL: Measuring Quality of Life; World Health Organization: Geneva, Switzerland, 1997.

26. Skevington, S.; Lofty, M.; O'connel, K.A. The World Health Organization's WHOQOL-BREF quality of life assessment: Psychometric properties and results of the international field trial. A Report from the WHOQOL Group. Qual. Life Res. 2004, 13, 299-310. [CrossRef]

27. Ohaeri, J.U.; Awadalla, A.W. The reliability and validity of the short version of the WHO Quality of Life Instrument in an Arab general population. Ann. Saudi Med. 2009, 29, 98-104. [CrossRef]

28. Jaracz, K.; Kalfoss, M.; Górna, K.; Bączyk, G. Quality of life in Polish respondents: Psychometric properties of the Polish WHOQOL-Bref. Scand. J. Caring Sci. 2006, 20, 251-260. [CrossRef] [PubMed]

29. Özkan, M.; Solmaz, B. Generation Z-The global market's new consumers-And their consumption habits: Generation Z consumption scale. Eur. J. Multidiscip. Stud. 2017, 2, 150-157. [CrossRef]

30. Moore, K.; Jones, C.; Frazier, R.S. Engineering education for generation Z. Am. J. Eng. Educ. 2017, 8, 111-126. [CrossRef]

31. Reeves, T.C.; Oh, E. Generational differences. In Handbook of Research on Educational Communications and Technology, 3rd ed.; Spector, J.M., Merrill, M.D., Ellen, J., Bishop, M.J., Eds.; Springer: New York, NY, USA, 2008; pp. 295-303.

32. Kapil, Y.; Roy, A. Critical evaluation of generation Z at workplaces. Int. J. Soc. Relev. Concern 2014, 2, 10-14.

33. Poláková, P.; Klímová, B. Mobile technology and generation Z in the English language classroom: A preliminary study. Educ. Sci. 2019, 9, 203. [CrossRef]

34. Singh, A.P.; Dangmei, J. Understanding the generation Z: The future workforce. South-Asian J. Multidiscip. Study 2016, 3, 1-5.

35. Chisholm, L.; Hurrelmann, K. Adolescence in modern Europe: Pluralized transition patterns and their implications for personal and social risks. J. Adolesc. 1995, 18, 129-158. [CrossRef]

36. Rindfuss, R.R. The young adult years: Diversity, structural change and fertility. Demography 1991, 28, 493-512. [CrossRef] 
37. Arnett, J.; Taber, S. Adolescence terminable and interminable: When does adolescence end? J. Youth Adolesc. 1994, 23, 517-537. [CrossRef]

38. Arnett, J. Emerging adulthood: A theory of development from the late teens through the twenties. Am. Psychol. 2000, 55, 469-480. [CrossRef]

39. DeMers, S.T.; Turner, S.M.; Andberg, M.; Foote, W.; Hough, L.; Ivnik, R.; Meier, S.; Moreland, K.; Rey-Casserly, C.M. Report of the Task Force on Test User Qualifications; Practice and Science Directorates, American Psychological Association: Washington, DC, USA, 2000.

40. Hornowska, E. Testy Psychologiczne. Teoria i Praktyka; Wydawnictwo Naukowe Scholar: Warsaw, Poland, 2001.

41. Juczyński, Z. Narzędzia Stosowane w Promocji i Psychologii Zdrowia; Psychological Test Laboratory of the PPA: Warsaw, Poland, 2001.

42. Brzezińska, A. Społeczna Psychologia Rozwoju; Wydawnictwo Naukowe Scholar: Warsaw, Poland, 2000.

43. Panek, T.; Zwierzchowski, J. Statystyczne Metody Wielowymiarowej Analizy Porównawczej. Teoria i Zastosowanie; Oficyna Wydawnicza Szkoła Główna Handlowa: Warsaw, Poland, 2013.

44. Gatnar, E.; Walesiak, M. Metody Statystycznej Analizy Wielowymiarowej w Badaniach Marketingowych; Wydawnictwo Akademii Ekonomicznej im. Oskara Langego we Wrocławiu: Wrocław, Poland, 2004.

45. Spearman, C. Correlation calculated from faulty data. Br. J. Psychol. 1910, 3, 271-295. [CrossRef]

46. Brown, W. Some experimental results in the correlation of mental abilities. Br. J. Psychol. 1910, 3, $296-322$.

47. Radoń, S. Fryburski inwentarz uważności FIU-14 (Polska adaptacja i walidacja Freiburg Mindfulness Inventory). Study Psychol. UKSW 2017, 17, 85-100. [CrossRef]

48. Bacro, F.; Coudronnière, C.; Gaudonville, T.; Galharret, J.-M.; Ferrière, S.; Florin, A.; Philippe Guimard, P. The French adaptation of the Satisfaction with Life Scale (SWLS): Factorial structure, age, gender and time-related invariance in children and adolescents. Eur. J. Dev. Psychol. 2020, 17, 307-316. [CrossRef]

49. Meule, A.; Voderholzer, U. Life satisfaction in persons with mental disorders. Qual. Life Res. 2020, 29, 3043-3052. [CrossRef]

50. Akın Arıkan, Ç.; Zorbaz, S. Measurement invariance of the satisfaction with life scale across gender and time. Turk. J. Educ. 2020, 9, 260-272. [CrossRef]

51. Reeves, A.J.; Baker, R.T.; Casanova, M.P.; Cheatham, S.W.; Pickering, M.A. Examining the factorial validity of the Quality of Life Scale. Health Qual. Life Outcomes 2020, 18, 32. [CrossRef]

52. Huang, V.; Fiocco, A.J. Measuring Perceived Receipt of Filial Piety among Chinese Middle-Aged and Older Adults. J. Cross Cult. Gerontol. 2020, 35, 195-208. [CrossRef]

53. Choi, G.; Park, S.G.; Won, Y.; Ju, H.; Jang, S.W.; Kim, H.D.; Jang, H.S.; Kim, H.C.; Leem, J.H. The relationship between precarious employment and subjective well-being in Korean wage workers through the Cantril ladder Scale. Ann. Occup. Environ. Med. 2020, 32, e11. [CrossRef]

54. Rosén, H.; Ahlström, G.; Lexén, A. Psychometric properties of the WHOQOL-BREF among next of kin to older persons in nursing homes. Health Qual. Life Outcomes 2020, 18, 103. [CrossRef]

55. Iqbal, M.S.; Kassab, Y.W.; Al-Saikhan, F.I.; Almalki, Z.S.; Haseeb, A.; Iqbal, M.Z.; Ali, M. Assessing quality of life using WHOQOLBREF: A cross-sectional insight among patients on warfarin in Malaysia. Saudi Pharm. J. 2020, 28, 936-942. [CrossRef] [PubMed]

56. Abbasi-Ghahramanloo, A.; Soltani-Kermanshahi, M.; Mansori, K.; Khazaei-Pool, M.; Sohrabi, M.; Baradaran, H.R.; Talebloo, Z.; Gholami, A. Comparison of SF-36 and WHOQoL-BREF in measuring quality of life in patients with type 2 diabetes. Int. J. Gen. Med. 2020, 13, 497-506. [CrossRef] [PubMed]

57. Kwarciński, T.; Ulman, P. Quality of life paradox. Well-being ranking of the selected European countries based on hybrid well-being approach. Econ. Sociol. 2020, 13, 160-180. [CrossRef]

58. Zamfir, E. Quality of life and social justice in Romania: Measuring quality of life. Rev. Cercet. Interv. Soc. 2017, $59,34-53$.

59. Nevado-Peña, D.; López-Ruiz, V.-R.; Alfaro-Navarro, J.-L. Improving quality of life perception with ICT use and technological capacity in Europe. Technol. Forecast. Soc. Chang. 2019, 148, 119734. [CrossRef]

60. Nováková, B.; Šoltés, V. Quality of life research: Material living conditions in the visegrad group countries. Econ. Soc. 2016, 9, 282-294. [CrossRef]

61. Koronakos, G.; Smirlis, Y.; Sotiros, D.; Despotis, D.K. Assessment of OECD Better Life Index by incorporating public opinion. Socio-Econ. Plan. Sci. 2020, 70, 100699. [CrossRef]

62. Paniagua, J.; Peiró-Palomino, J.; Picazo-Tadeo, A.J. Asylum Migration in OECD Countries: In Search of Lost Well-Being. Soc. Indic. Res. 2020, 1-29. [CrossRef]

63. Polat, E. The classification of OECD countries in terms of life satisfaction using partial least squares discriminant analysis. Sak. Univ. J. Sci. 2020, 24, 365-376. [CrossRef]

64. Kobus, M.; Półchłopek, O.; Yalonetzky, G. Inequality and welfare in quality of life among OECD countries: Non-parametric treatment of ordinal data. Soc. Indic. Res. 2019, 143, 201-232. [CrossRef] 